\title{
タイ北部山岳少数民族の食生活と保健要因への認識
}

\author{
平井和子 $* 1$ - 大野佳美 $* 2$ - 中山ニーパー*1 - 岡崎久美*1 - 薗田雅子*3 - 古崎和代 $* 4$. \\ 長谷川めぐみ*4・八木千鶴*5 \\ $(* 1$ 大阪市立大学大学院生活科学研究科, $* 2$ 武庫川女子大学生活環境学部, \\ $* 3$ 畿央大学, $* 4$ 天使大学, $* 5$ 千里金蘭大学)
}

\section{Food intake and views on health among elementary school students and adults living in northern Thailand}

\author{
Kazuko Hirai*1, Yoshimi Ohno*2, Nipa Nakayama*1, Kumi Okazaki*1, \\ Masako Sonoda*3, Kazuyo Furusaki*4, Megumi Hasegawa*4, Chizuru Yagi*5 \\ ${ }^{* 1}$ Graduate School of Human Life Science, Osaka City University, 3-3-138 Sugimoto, Sumiyoshi-ku, Osaka, \\ 558-8585 \\ ${ }^{* 2}$ School of Human Environmental Sciences, Mukogawa Women's University, 6-46 Ikebiraki-cho, \\ Nishinomiya, 663-8558 \\ ${ }^{* 3}$ Kio University, 4-2-2, Umami-naka, Koryo-cho, Kitakatsuragi-gun, Nara, 635-0832 \\ ${ }^{* 4}$ Tenshi College, North-13, East-3, Higashi-ku, Sapporo, 065-0013 \\ ${ }^{* 5}$ Senri Kinran University, 5-25-1 Fujishirodai, Suita-city, Osaka, 565-0873 \\ ${ }^{* 1}$ 于558-8585 大阪市住吉区杉本 3-3-138 \\ *2 $7663-8558$ 兵庫県西宮市池開町 6-46 \\ *3 $7635-0832$ 奈良県北葛城郡広陵町馬見中 4-2-2 \\ *4 $\mathbf{T} 065-0013$ 札幌市東区北13条東 3-31-2 \\ *5 个565-0873 吹田市藤白台 5-25-1
}

In order to compare the food intake and views on health of elementary school students and adults living in northern Thailand, a questionnaire survey was conducted that included 72 male and 73 female students and 65 males and 45 females aged 15 to 59 years.

With respect to their food intake frequencies, $91 \%$ and $99 \%$ responded "every day" for rice and $72 \%$ and $79 \%$ for vegetables among the male and female students, respectively, and $97 \%$ and $95 \%$ for rice and $63 \%$ and $88 \%$ for vegetables among the male and female adults, respectively. Three regular meals were taken by $74 \%$ and $80 \%$ of the male and female students, respectively, and $91 \%$ and $91 \%$ of the male and female adults, respectively $(\mathrm{p}<0.05$ for males between students and adults).

When asked about the pleasure of having meals with their family while chatting, 47 $\%$ and $69 \%$ of the male and female students, respectively, and $91 \%$ and $91 \%$ of the male and female adults, respectively, responded positively $(\mathrm{p}<0.05$ between gender in students and $p<0.001$ for males and $p<0.05$ for females between students and adults). Reports of sleeping well came from $36 \%$ and $54 \%$ of the male and female students, and $47 \%$ and $66 \%$ of the male and female adults $(\mathrm{p}<0.05$ between gender in students).

A significant correlation was found between the food intake frequencies of vegetables and the degree of sleeping $(\mathrm{p}<0.05$ for students and adults, respectively). The greater intake frequencies of vegetables showed a correlation with more human com- 
munication ( $\mathrm{p}<0.05$ and $\mathrm{p}<0.01$ for students and adults, respectively).

The present results indicated that lower food intake levels lead to a lower nutritional status, and the lower intake frequencies of vegetables can affect the degree of sleep and of human communication.

\section{緒言}

タイ王国の経済発展はめざをしいが，都市部と地方と の所得格差が問題となっている。宇都宮らは1) 3) タイ山 村の児童·生徒は伝統的生活を維持しているが，情報化 が都市部への憧れや弊害ももたらしていることを報告し ている。

タイ北部山岳地帯には独自の文化と伝統をもつモン族, カレン族，アカ族などの少数民族が居住している ${ }^{4) ~ 6) 。 ~}$ ミャンマーやラオスに接する国境山岳地帯は麻薬黄金の 三角地帯といわれ，山岳少数民族の主な収入源はアヘン

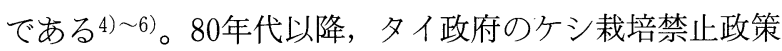
に伴って野菜，果物などの農業が奨励されているが，年 間所得は 3500 バーツ程度と都市部の 1 / 5 以下と推定さ れ経済状態は悪(4) 6)。更に焼畑移動耕作から定住化し た生活様式への变貌など山岳少数民族の生活環境が顕著 に変動している。

このような状況下におけるタイ北部山岳少数民族の食 生活の実態と保健要因や心的要因への認識を把握し，そ れらの関連性を検討するためにアンケート調査を行った。

\section{方法}

\section{1. 調査地}

調査地はタイ王国チェンマイ市の北西約 $40 \mathrm{~km}$ に位置 する標高 $1200 \mathrm{~m}$ のケシ栽培地域で, 現在はタイ政府の ケシ栽培禁止に伴ったタイ王室プロジェクトによる代替 野菜の栽培指導地域である ${ }^{4)}$ 6)。渓谷の斜面や山に井ま れた小さい盆地にレタス, 白菜などの野菜を栽培し, 収 穫した野菜は村の集積所に保管，包装されてバンコクな どの都会へ輸送，販売されている。

食文化としては，北部タイは雲南から東北タイシャン 高原に広がるもち米文化圏に属し，うるち米で作った麺 も簡易食として使用されている7)。飯, 麺, 野菜炒めな どに, 北部タイを代表する調味料である魚の塩漬汁を熟 成させたナンプーなどの汁をかけて食べることが多い7。 一般的な食事形態として, 朝食は蒸もち米飯, 卵焼きと 野菜炒め煮, 昼食は曙と朝食の残った副食, 夕食は蒸も ち米飯, 野菜スープ, 豚料理などであった。

\section{2. 調査対象および調査方法}

調査地区の人口は約 800 人で, 調査対象者はモン族 94.3 $\%$, カレン族 $1.9 \%$, その他 $3.8 \%$ で, 家族構成は 2 世代 家庭 $56.7 \% ， 3$ 世代家庭 $43.3 \%$ で，平均家族数は $6 \pm 3$ 名であった。対象者の $78.7 \%$ が農業に従事し, 兼業農家 $7.4 \%$, 商業 $2.8 \%$, 公務員 $1.9 \%$, その他 $9.2 \%$ であっ。 本質的には精霊崇拝の信仰体系をもち4) 6), 宗教は
仏教普及政策により仏教 $90.7 \%$, ヒンズー教やイスラム 教 $0.9 \%$ ，その他 $8.3 \%$ であった。

2003 年 8 月にノンホイカオ村に居住する住民 110 人 （男 65 人，女 45 人， 15 59歳）（以下家族とする）及び 4 年生 6 年生の小学生 145 人（男子 72 人, 女子 73 人）を 対象に, 食生活と健康に関連する項目についてアンケー ト調査を行い，更に項目間の関連性について検討した。 住民への調査はタイ語による記述質問調査用紙を用いて 訪問面接聞き取り調査を行った。小学生の調査は, タイ 語による記述質問調查用紙を配布後授業担当教員の説明 に従って回答を得た。

各調査項目の統計解析は SPSS（SPSS Base 10.0）を 用い，集計結果に対する $\chi^{2}$ 検定は分割表を用いて検討 し，有意水準は $5 \%$ 以下とした。

\section{結果}

\section{1. 喫煙と飲酒習慣}

契煙と飲酒習慣を表 1 に示したが，家族の契煙率は男 $20 \%$ で,「 1 日 20 本以上」 $3 \%, 「 1$ 日に $2 \sim 3$ 本」 $9 \%$, 「週に $2 \sim 3$ 本」 $8 \%$ で, 女の契煙者は $0 \%$ で契煙習慣 はなかった（性差 $\mathrm{p}<0.05 ） 。$ 飲酒習慣について男 $69 \%$ で，「毎日飲む」 $8 \%$,「週に $2 \sim 3$ 回」 $17 \%$, [飲まな い] $31 \%$ であった。女は「月に $2 \sim 3$ 回飲む」が $7 \%$, [飲まない] 93\%で男と比較して女の飲酒習慣は非常に 低かった（性差 $\mathrm{p}<0.001 ） 。$

\section{2. 食品摂取頻度}

食品摂取頻度を表 2 に示したが，穀類の摂取頻度を比 較すると, 米 (飯, 缅) は小学生では「毎日」は男女各 々 $91 \%$ と $99 \%$, 家族男女各々 $97 \%$ と $95 \%$ で，米の摂取頻 度が高かった。パンの「週に 1 回以下」は小学生, 家族 ともに $83 \%$ 以上，うどんは $88 \%$ 以上で，小麦の摂取頻度 が両群ともに低かった。とうもろこし等の雑穀の摂取頻

\section{表 1 家族の喫煙と飲酒習慣}

$(\%)$

\begin{tabular}{lrrr}
\hline 調查 項 目 & 男 & 女 & $\begin{array}{c}\text { 男女間の関連性 } \\
\left(\chi^{2} \text { 検定 }\right)\end{array}$ \\
\hline 契煙 & & & \\
1 日に 20 本以上 & 3.1 & 0.0 & \\
1 日に $2 \sim 3$ 本 & 9.4 & 0.0 & $\mathrm{p}<0.05$ \\
週に $2 \sim 3$ 本 & 7.8 & 0.0 & \\
$\quad$ 吸わない & 79.7 & 100.0 & \\
\hline 飲酒 & & & \\
毎日飲む & 7.8 & 0.0 & \\
週に $2 \sim 3$ 回飲む & 17.2 & 0.0 & \\
$\quad$ 月に $2 \sim 3$ 回飲む & 43.7 & 6.7 & \\
$\quad$ 飲むない & 31.3 & 93.3 & \\
\hline
\end{tabular}

(17) 161 
日本食生活学会誌 Vol.15 No.3（2004）

表 2 小学生と家族の食品摂取頻度

(\%)

\begin{tabular}{|c|c|c|c|c|c|c|c|c|c|}
\hline \multirow{2}{*}{ 食品群 } & \multirow{2}{*}{ 撕 取 頻 度 } & \multicolumn{3}{|c|}{ 小学生 } & \multicolumn{3}{|c|}{ 家族 } & \multicolumn{2}{|c|}{ 小学生と家族間の関連性 ${ }^{*}$} \\
\hline & & 男 & 女 & $\chi^{2}$ 検定 & 男 & 女 & $\chi^{2}$ 検定 & 男 & 女 \\
\hline \multirow{3}{*}{ 米 } & 毎日 & 90.9 & 98.6 & \multirow{3}{*}{ ns } & 96.8 & 95.4 & \multirow{3}{*}{ ns } & \multirow{3}{*}{ ns } & \multirow{3}{*}{ ns } \\
\hline & 週に 2 〜 回 & 3.0 & 0.0 & & 0.0 & 2.3 & & & \\
\hline & 週に 1 回以下 & 6.1 & 1.4 & & 3.2 & 2.3 & & & \\
\hline \multirow{3}{*}{ パン } & 毎日 & 0.0 & 2.8 & \multirow{3}{*}{ ns } & 1.6 & 2.3 & \multirow{3}{*}{ ns } & \multirow{3}{*}{ ns } & \multirow{3}{*}{ ns } \\
\hline & 週に 2 〜 回 & 7.2 & 6.9 & & 12.7 & 14.0 & & & \\
\hline & 週に 1 回以下 & 92.8 & 90.3 & & 85.7 & 83.7 & & & \\
\hline \multirow{3}{*}{ うどん } & 毎日 & 0.0 & 2.9 & & 0.0 & 4.8 & & & \\
\hline & 週に $2 \sim 3$ 回 & 5.7 & 2.9 & ns & 9.4 & 7.1 & ns & ns & ns \\
\hline & 週に 1 回以下 & 94.3 & 94.2 & & 90.6 & 88.1 & & & 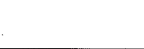 \\
\hline & 毎日 & 25.8 & 10.1 & & 3.2 & 2.3 & & & \\
\hline 杂倠穀 & 週に $2 \sim 3$ 回 & 9.7 & 8.7 & $\mathrm{~ns}$ & 17.7 & 34.9 & ns & $\mathrm{p}<0.01$ & $\mathrm{p}<0.01$ \\
\hline & 週に 1 回以下 & 64.5 & 81.2 & & 79.1 & 62.8 & & & \\
\hline & 毎日 & 7.4 & 1.4 & & 0.0 & 0.0 & & & \\
\hline 芋類 & 週に2 3 回 & 7.4 & 5.6 & ns & 14.1 & 27.9 & ns & $\mathrm{p}<0.05$ & $\mathrm{p}<0.01$ \\
\hline & 週に 1 回以下 & 85.2 & 93.0 & & 85.9 & 72.1 & & & \\
\hline & 毎日 & 7.4 & 5.8 & & 1.6 & 7.0 & & & \\
\hline 豆類 & 週に 2 〜 回 & 19.1 & 31.9 & ns & 27.0 & 32.6 & ns & ns & ns \\
\hline & 週に 1 回以下 & 73.5 & 62.3 & & 71.4 & 60.4 & & & \\
\hline & 毎日 & 4.7 & 4.3 & & 1.6 & 0.0 & & & \\
\hline 種実類 & 週に 2 〜 回 & 7.8 & 12.9 & ns & 7.9 & 19.0 & ns & ns & ns \\
\hline & 週に 1 回以下 & 87.5 & 82.8 & & 90.5 & 81.0 & & & \\
\hline & 毎日 & 72.1 & 79.4 & & 62.9 & 88.3 & & & \\
\hline 野菜 & 週に 2 〜 3 回 & 14.7 & 13.2 & ns & 25.8 & 7.0 & $\mathrm{p}<0.05$ & ns & $\mathrm{p}<0.01$ \\
\hline & 週に 1 回以下 & 13.2 & 7.4 & & 11.3 & 4.7 & & & \\
\hline & 毎日 & 13.8 & 7.2 & & 6.3 & 21.4 & & & \\
\hline 果物類 & 週に 2 〜 回 & 36.9 & 31.9 & ns & 47.6 & 42.9 & ns & ns & $\mathrm{p}<0.05$ \\
\hline & 週に 1 回以下 & 49.3 & 60.9 & & 46.1 & 35.7 & & & \\
\hline & 毎日 & 4.5 & 2.8 & & 4.8 & 0.0 & & & \\
\hline 魚介類 & 週に $2 \sim 3$ 回 & 10.6 & 7.0 & ns & 12.7 & 22.5 & ns & ns & $\mathrm{p}<0.05$ \\
\hline & 週に 1 回以下 & 84.9 & 90.2 & & 82.5 & 77.5 & & & \\
\hline & 毎日 & 14.7 & 15.5 & & 20.6 & 52.4 & & & \\
\hline 肉類 & 週に $2 \sim 3$ 回 & 30.9 & 33.8 & ns & 50.8 & 33.3 & $\mathrm{p}<0.01$ & $\mathrm{p}<0.05$ & $\mathrm{p}<0.001$ \\
\hline & 週に 1 回以下 & 54.4 & 50.7 & & 28.6 & 14.3 & & & \\
\hline & 毎日 & 30.9 & 19.1 & & 12.5 & 35.7 & & & \\
\hline 卵類 & 週に 2 〜 回 & 29.4 & 44.1 & ns & 64.1 & 45.3 & $\mathrm{p}<0.05$ & $\mathrm{p}<0.001$ & ns \\
\hline & 週に 1 回以下 & 39.7 & 36.8 & & 23.4 & 19.0 & & & \\
\hline & 毎日 & 22.6 & 24.3 & & 1.6 & 7.1 & & & \\
\hline 牛乳 & 週に 2 〜 回 & 12.9 & 12.9 & ns & 20.3 & 31.0 & ns & $\mathrm{p}<0.01$ & $\mathrm{p}<0.05$ \\
\hline & 週に 1 回以下 & 64.5 & 62.8 & & 78.1 & 61.9 & & & \\
\hline & 毎日 & 9.9 & 7.2 & & 3.1 & 4.8 & & & \\
\hline 乳製品 & 週に 2 〜 回 & 14.1 & 5.8 & $\mathrm{~ns}$ & 15.6 & 16.7 & ns & $\mathrm{ns}$ & ns \\
\hline & 週に 1 回以下 & 76.0 & 87.0 & & 81.3 & 78.5 & & & \\
\hline & 毎日 & 72.5 & 71.0 & & 49.3 & 59.5 & & & \\
\hline 動物脂 & 週に 2 〜 回 & 15.9 & 5.8 & ns & 19.0 & 14.3 & ns & $\mathrm{p}<0.01$ & $\mathrm{~ns}$ \\
\hline & 週に 1 回以下 & 11.6 & 23.2 & & 31.7 & 26.2 & & & \\
\hline & 毎日 & 17.4 & 11.6 & & 29.7 & 50.0 & & & \\
\hline 植物油 & 週に $2 \sim 3$ 回 & 24.6 & 21.7 & $\mathrm{~ns}$ & 15.6 & 25.0 & $\mathrm{p}<0.05$ & ns & $\mathrm{p}<0.001$ \\
\hline & 週に 1 回以下 & 58.0 & 66.7 & & 54.7 & 25.0 & & & \\
\hline & 毎日 & 7.5 & 1.4 & & 3.2 & 2.4 & & & \\
\hline 茶 & 週に $2 \sim 3$ 回 & 6.0 & 1.4 & ns & 6.3 & 7.3 & ns & ns & ns \\
\hline & 週に 1 回以下 & 86.5 & 97.2 & & 90.5 & 90.3 & & & \\
\hline & 毎日 & 5.6 & 2.8 & & 10.9 & 2.3 & & & \\
\hline 嗜好飲料 & 週に $2 \sim 3$ 回 & 18.3 & 15.5 & ns & 23.4 & 9.3 & $\mathrm{p}<0.05$ & ns & ns \\
\hline & 週に 1 回以下 & 76.1 & 81.7 & & 65.7 & 88.4 & & & \\
\hline
\end{tabular}


度は小学生では「毎日」は男女各々 $26 \%$ と $10 \%$ あっむた のに対して家族では男女とも $3 \%$ 以下と少なかった（小 学生と家族間差, 男女各々 $\mathrm{p}<0.01)$ 。

芋類々豆類の摂取頻度をみると,「週に 1 回以下」が 小学生，家族ともにそれぞれ $72 \%$ 以上と $60 \%$ 以上で，芋 類と豆類の摂取頻度が低かった。野菜類の「毎日」摂取 は，小学生は男女各々 $72 \%$ と79\%で，家族は男 $63 \%$ に対 して女 $88 \%$ と多かった（家族性差 $\mathrm{p}<0.05 ） 。$ 。 女 では小学生の摂取頻度が家族よりも低かった（小学生之 家族間差，女 $\mathrm{p}<0.01) 。$

魚介類の「週に 1 回以下」の摄取は, 小学生, 家族と もに $77 \%$ 以上と魚介類の摂取頻度が低かった（小学生と 家族間差，女 $\mathrm{p}<0.05)$ 。肉類の摂取頻度は，小学生で 「毎日」は男女各々 $15 \%$ と $16 \%$ ，「週に 1 回以下」が54\% と51\%であった。家族では「毎日」は男 $21 \%$ に対して女 $52 \%$ と多加た（家族性差 $\mathrm{p}<0.01 ） 。$ 。，男女とも に小学生の摂取頻度が家族よりも低かった（小学生と家 族間差，男 $\mathrm{p}<0.05 ， 女 \mathrm{p}<0.001)$ 。

卵類は，小学生では「毎日」は男女各々 $31 \%$ と $19 \%$,
「週に 1 回以下」が36\%以上で卵類の摂取頻度が低かっ た。家族では「毎日」は男13\%に対して女 $36 \%$ と多かっ

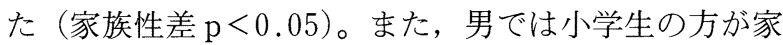
族よりも摂取頻度が低かった（小学生と家族間差, 男 $\mathrm{p}<0.001)$ 。

牛乳は「毎日」が男女各々小学生 $23 \%$ と $24 \%$,「週に 1 回以下」が65\%と63\%で男女ともに摂取頻度が低かっ た。家族では「毎日」は7\%以下で，小学生よりも更に 牛乳の摂取頻度が低かった（小学生と家族間差，男 $\mathrm{p}<$ 0.01 ，女 $\mathrm{p}<0.05)$ 。乳製品の摂取頻度は，「毎日」は小 学生と家族ともに $10 \%$ 以下で, $76 \%$ 以上が「週に 1 回以 下」と乳製品の摂取頻度が低かった。

油脂類の摂取頻度を比較すると, 動物脂の「毎日」は 男女各々小学生 $73 \%$ と $71 \%$ に対して家族 $49 \%$ と $60 \%$ と少 なかった（小学生と家族間差，男 $\mathrm{p}<0.01$ )。植物油の 「毎日」は，小学生は男女各々 $17 \%$ と $12 \%$ で，家族の方 が30\%と50\%と多かった（家族性差 $\mathrm{p}<0.05$ ，小学生と 家族間差，女 $\mathrm{p}<0.001)$ 。

飲料を比較すると, 茶の摂取頻度は小学生, 家族とも

表 3 食生活と保健要因に対する認識

\begin{tabular}{|c|c|c|c|c|c|c|c|c|}
\hline \multirow{2}{*}{ 調 査 項 目 } & \multicolumn{2}{|c|}{ 小学生 } & \multirow[b]{2}{*}{$\chi^{2 \text { 検定 }}$} & \multicolumn{3}{|c|}{ 家族 } & \multicolumn{2}{|c|}{ 小学生と家族間の関連性 } \\
\hline & 男 & 女 & & 男 & 女 & $\chi^{2 \text { 検定 }}$ & 男 & 女 \\
\hline \multicolumn{9}{|l|}{ 欠食状況 } \\
\hline 欠食しない & 74.2 & 80.2 & \multirow{3}{*}{$\mathrm{ns}$} & 90.6 & 90.9 & \multirow{3}{*}{ ns } & \multirow{3}{*}{$\mathrm{p}<0.05$} & \multirow{3}{*}{ ns } \\
\hline 時々欠食する & 15.2 & 11.3 & & 7.8 & 6.8 & & & \\
\hline よく欠食する & 10.6 & 8.5 & & 1.6 & 2.3 & & & \\
\hline \multicolumn{7}{|c|}{ 仕事, 家事, 運動などで体を動かしている時間 } & \multirow{5}{*}{$\mathrm{p}<0.001$} & \multirow{5}{*}{$\mathrm{p}<0.01$} \\
\hline 7 時間以上/日 & 18.0 & 22.0 & \multirow{4}{*}{ ns } & 78.2 & 55.9 & \multirow{4}{*}{$\mathrm{p}<0.05$} & & \\
\hline $3 \sim 4$ 時間/日 & 38.0 & 32.0 & & 9.1 & 30.2 & & & \\
\hline $1 \sim 2$ 時間/日 & 34.0 & 28.0 & & 9.1 & 11.6 & & & \\
\hline 殆ど何もしていない & 10.0 & 18.0 & & 3.6 & 2.3 & & & \\
\hline \multicolumn{9}{|l|}{ 体重 } \\
\hline 瘦せたい & 6.0 & 22.2 & \multirow{3}{*}{$\mathrm{p}<0.05$} & 15.9 & 13.6 & \multirow{3}{*}{ ns } & \multirow{3}{*}{$\mathrm{p}<0.05$} & \multirow{3}{*}{ ns } \\
\hline 今のままでよい & 89.5 & 73.6 & & 69.8 & 75.0 & & & \\
\hline 太りたい & 4.5 & 4.2 & & 14.3 & 11.4 & & & \\
\hline \multicolumn{9}{|l|}{ 睡眠 } \\
\hline 熟睡 & 35.8 & 53.7 & \multirow{3}{*}{$\mathrm{p}<0.05$} & 46.8 & 65.9 & \multirow{3}{*}{ ns } & \multirow{3}{*}{ ns } & \multirow{3}{*}{ ns } \\
\hline 時々眠れない & 44.8 & 38.8 & & 43.5 & 31.8 & & & \\
\hline ぐっすり眠れない & 19.4 & 7.5 & & 9.7 & 2.3 & & & \\
\hline \multicolumn{9}{|l|}{ 体調 } \\
\hline よい & 27.9 & 27.3 & \multirow{3}{*}{ ns } & 20.3 & 18.2 & & & \\
\hline 普通 & 64.7 & 68.2 & & 54.7 & 56.8 & ns & $\mathrm{p}<0.05$ & $\mathrm{p}<0.01$ \\
\hline 疲れている & 7.4 & 4.5 & & 25.0 & 25.0 & & & \\
\hline 健康に適した食生活をし & & & & & & & & \\
\hline はい & 78.0 & 82.8 & & 64.1 & 77.3 & & & \\
\hline いいえ & 13.2 & 14.3 & ns & 25.0 & 13.6 & ns & ns & ns \\
\hline どちらともいえない & 8.8 & 2.9 & & 10.9 & 9.1 & & & \\
\hline 楽しく過ごしている & & & & & & & & \\
\hline はい & 72.9 & 80.5 & & 88.7 & 79.5 & & & \\
\hline いいえ & 7.1 & 4.2 & ns & 9.7 & 9.1 & ns & $\mathrm{p}<0.001$ & ns \\
\hline どちらともいえない & 20.0 & 15.3 & & 1.6 & 11.4 & & & \\
\hline 人間関係に満足している & & & & & & & & \\
\hline はい & 63.4 & 71.8 & & 84.3 & 93.2 & & & \\
\hline いいえ & 21.1 & 16.9 & ns & 9.4 & 4.5 & $\mathrm{~ns}$ & $\mathrm{p}<0.05$ & $\mathrm{p}<0.05$ \\
\hline どちらともいえない & 15.5 & 11.3 & & 6.3 & 2.3 & & & \\
\hline
\end{tabular}


日本食生活学会誌 Vol.15 No.3（2004）

に「毎日」は $8 \%$ 以下と少なかった。コーヒー・ジュー ス等の飲料は, 小学生では「毎日」は $6 \%$ 以下で, 家族 では女（2\%）よりも男（11\%）の摂取頻度が高かった (家族性差 $\mathrm{p}<0.05)$ 。

種実類の「週に 1 回以下」が小学生と家族ともに $81 \%$ 以上と摂取が少なかった。果実類は，小学生と家族とも に「毎日」が21\%以下で,「週に 1 回以下」が小学生々 家族ともに 36 ～ $61 \%$ と摂取が少なかった（小学生と家族 間差, 女 $\mathrm{p}<0.05)$ 。

\section{3. 食生活と保健要因に対する認識（表 3 ）}

食事の欠食状況は, 小学生では男女各々「欠食しない」 は74\%と $80 \%$,「時々欠食する」15\%と11\%，「よく欠食 する」11\%と9\%であった。家族では，「欠食しない」 $90 \%$ 以上，「よく久食する」 $3 \%$ 以下で，家族よりも喫
食率が低い傾向がみられた（小学生と家族間差，男 $\mathrm{p}<$ $0.05)$ 。

仕事，家事，運動などで 1 日に体を動かす時間は小学 生で「7 時間以上」が男女各々 $18 \%$ と $22 \%, 「 3 \sim 4$ 時 間」38\%と32\%と男女同程度であった。家族では「7 時 間以上」が男 $78 \%$ に対して女 $56 \%$ と少なかった（家族性 差 $\mathrm{p}<0.05)$ 。また, 小学生と比べて家族の方が男女と もに「体を動かす時間」が長かった（小学生と家族間差， 男 $\mathrm{p}<0.001$, 女 $\mathrm{p}<0.01)$ 。体重に対して小学生では 「今のままでよい」が90\%と74\%で，「瘦せたい」が男子 $6 \%$ に対して女子 $22 \%$ と多かった（小学生性差 $\mathrm{p}<0.05$ )。 家族では「瘦せたい」が男女各々 $16 \%$ と $14 \%$ で，「今の ままでよい」が70\%と75\%であった。

睡眠に対して「熟睡」が小学生で男 $36 \%$ に対して女54

表 4 健康に関わる心的要因に対する認識

(\%)

\begin{tabular}{|c|c|c|c|c|c|c|c|c|}
\hline \multirow{2}{*}{ 調 査 項 目 } & \multicolumn{3}{|c|}{ 小学生 } & \multicolumn{3}{|c|}{ 家 } & \multicolumn{2}{|c|}{ 小学生と家族間の関連性 } \\
\hline & 男 & 女 & $\chi^{2}$ 検定 & 男 & 女 & $\chi^{2}$ 検定 & 男 & 女 \\
\hline \multicolumn{9}{|c|}{ 家族と食事をしながら話をすることが楽しみである } \\
\hline はい & 47.0 & 68.6 & \multirow{3}{*}{$\mathrm{p}<0.05$} & 90.5 & 90.9 & \multirow{3}{*}{ ns } & \multirow{3}{*}{$\mathrm{p}<0.001$} & \multirow{3}{*}{$\mathrm{p}<0.05$} \\
\hline いいえ & 39.4 & 24.3 & & 7.9 & 9.1 & & & \\
\hline どちらともいえない & 13.6 & 7.1 & & 1.6 & 0.0 & & & \\
\hline \multicolumn{9}{|c|}{ 日常生活上の仕事を家族全員で分担しなければならない } \\
\hline はい & 65.7 & 61.6 & \multirow{3}{*}{ ns } & 63.5 & 61.9 & \multirow{3}{*}{ ns } & \multirow{3}{*}{ ns } & \multirow{3}{*}{ ns } \\
\hline いいえ & 20.9 & 23.3 & & 25.4 & 31.0 & & & \\
\hline どちらともいえない & 13.4 & 15.1 & & 11.1 & 7.1 & & & \\
\hline \multicolumn{9}{|l|}{ 家族に役立ちたいと思う } \\
\hline はい & 77.4 & 91.8 & \multirow{3}{*}{$\mathrm{ns}$} & 98.4 & 93.2 & \multirow{3}{*}{ ns } & \multirow{3}{*}{$\mathrm{p}<0.001$} & \multirow{3}{*}{ ns } \\
\hline いいえ & 12.7 & 5.5 & & 1.6 & 4.5 & & & \\
\hline どちらともいえない & 9.9 & 2.7 & & 0.0 & 2.3 & & & \\
\hline \multicolumn{9}{|c|}{ 伝統的な習慣は人々の紏や支えになっている } \\
\hline はい & 69.6 & 76.4 & \multirow{3}{*}{ ns } & 93.7 & 95.5 & \multirow{3}{*}{ ns } & \multirow{3}{*}{$\mathrm{p}<0.01$} & \multirow{3}{*}{$\mathrm{p}<0.05$} \\
\hline いいえ & 20.3 & 16.7 & & 4.7 & 4.5 & & & \\
\hline どちらともいえない & 10.1 & 6.9 & & 1.6 & 0.0 & & & \\
\hline \multicolumn{7}{|l|}{ 働くことへの認識 } & & \\
\hline 家族のため & 46.5 & 51.5 & & 62.7 & 76.3 & & & \\
\hline 収入のため & 10.1 & 6.1 & $\mathrm{~ns}$ & 10.2 & 7.1 & ns & $\mathrm{p}<0.001$ & $\mathrm{p}<0.05$ \\
\hline 当然の義務 & 27.5 & 22.7 & & 22.0 & 7.1 & & & \\
\hline 働けることが幸福 & 15.9 & 19.7 & & 5.1 & 9.5 & & & \\
\hline 生活上の情報源 & & & & & & & & \\
\hline 家族‧親戚 & 42.9 & 68.7 & & 47.8 & 40.0 & & & \\
\hline 近所の人 & 16.3 & 10.4 & & 18.2 & 2.9 & & & \\
\hline 友人 & 20.4 & 16.7 & $\mathrm{p}<0.05$ & 0.0 & 0.0 & $\mathrm{p}<0.05$ & $\mathrm{p}<0.05$ & $\mathrm{p}<0.001$ \\
\hline ラジオ，テレビ等 & 20.4 & 2.1 & & 29.5 & 57.1 & & & \\
\hline その他 & 0.0 & 2.1 & & 4.5 & 0.0 & & & \\
\hline 日常生活における楽しる & & & & & & & & \\
\hline 会話 & 18.6 & 24.9 & & 38.8 & 45.9 & & & \\
\hline スポーツ & 49.9 & 29.7 & & 6.1 & 8.3 & & & \\
\hline 祭などの行事 & 22.9 & 29.7 & ns & 34.7 & 20.8 & ns & $\mathrm{p}<0.001$ & $\mathrm{p}<0.05$ \\
\hline ラジオ, テレビ等 & 4.3 & 9.4 & & 14.3 & 25.0 & & & \\
\hline 旅行 & 4.3 & 6.3 & & 6.1 & 0.0 & & & \\
\hline 現在最も望むこと & & & & & & & & \\
\hline 健康 & 40.0 & 53.6 & & 36.1 & 47.5 & & & \\
\hline 裕福 & 7.7 & 2.8 & ns & 9.8 & 15.0 & ns & ns & ns \\
\hline 出世 & 47.7 & 36.6 & & 47.5 & 27.5 & & & \\
\hline その他 & 4.6 & 7.0 & & 6.6 & 10.0 & & & \\
\hline
\end{tabular}

$164(20)$ 
\%と多く，「時々眠れない」が男女各々 $45 \%$ と $39 \%$,「ぐ っすり眠れない」 $19 \%$ と $8 \%$ であった（小学生性差 $\mathrm{p}<$ 0.05)。家族では「熟睡」が46\%以上で，「時々眠れない」 が31\%以上であった。現在の体調について，「よい」は 小学生で $27 \%$ 以上,「疲れている」 $8 \%$ 以下であった。 家族では男女各々「よい」が $18 \%$ 以上，「疲れている」 が $25 \%$ と多く，小学生と比べて男女ともに家族の方が 「疲れている」が多かった（小学生と家族間差, 男 $\mathrm{p}<$ 0.05 , 女 $\mathrm{p}<0.01)$ 。

「健康に適した食生活をしている」と答えた割合は小 学生で78\%以上，「していない」15\%以下であった。家 族では「健康に適した食生活をしている」は男女各々 64 $\%$ 以上，「していない」は $13 \%$ 以下で，食生活の健康度 への認識は小学生と家族で男女ともに同程度であった。

毎日の生活について「楽しく過ごしている」と答えた 割合は小学生では $72 \%$ 以上，家族は79\%以上で，男で小 学生の方が家族よりも楽しく過ごしている割合が少なか った（小学生と家族間差，男 $\mathrm{p}<0.001$ )。「人間関係に 満足している」と答えた割合は小学生では $63 \%$ 以上，家 族は $84 \%$ 以上で，小学生の方が家族よりも人間関係への 満足度が低かった（小学生と家族間差，男女各々 $\mathrm{p}<$ $0.05)$ 。

\section{4. 健康に関わる心的要因に対する認識（表 4）}

「家族と食事をしながら話をすることが楽しみである」 と答えた割合は，小学生で男 $47 \%$ に対して女 $69 \%$ と多か った（小学生性差 $\mathrm{p}<0.05 ） 。$ 家族では男女各々「はい」 が $90 \%$ 以上で，小学生よりも家族の方が団欒を楽しみに していることが認められた（小学生と家族間差, 男 $\mathrm{p}<$ 0.001 , 女 $\mathrm{p}<0.05)$ 。

「日常生活上の仕事を家族全員で分担しなければなら ない」に対して，「はい」は小学生と家族ともに $61 \%$ 以 上であった。「家族の役に立ちたい」は，小学生で男女 各々 $77 \%$ と $92 \%$ と多く, 家族 $98 \%$ と $93 \%$ で，男で小学生 の方が家族よりも少なかった（小学生と家族間差, 男 $\mathrm{p}<0.001)$ 。「伝統的な習慣は人々の絆や支えになって いる」と答えた割合は, 小学生男女各々 $69 \%$ 以上に対し て家族では $93 \%$ 以上と多かった（小学生と家族間差，男 $\mathrm{p}<0.01$, 女 $\mathrm{p}<0.05)$ 。
働くことへの認識について小学生では「家族のため」 が男女各々 $47 \%$ と $52 \%$ と最も多く, 次に「当然の義務」, 「働けることが幸福」の順であった。家族では「家族の ため」が男女各々 $63 \%$ と $76 \%$ と最も多く，「当然の義務」, 「収入のため」の順で，小学生と比べて「家族のため」 が多かった（小学生と家族間差，男 $\mathrm{p}<0.001$, 女 $\mathrm{p}<$ $0.05)$ 。

生活上の情報源は小学生では「家族・親戚」が男 $43 \%$ に対して女 $69 \%$ と多く, 男では「友人」や「ラジオ等」 が多かった（小学生性差 $\mathrm{p}<0.05 ） 。$ 家族では「家族・ 親戚」が男女各々 $48 \%$ と $40 \%$ で，「ラジオ等」は男 $30 \%$ に対して女 $57 \%$ と多かった（家族性差 $\mathrm{p}<0.05 ） 。$ 。， 小学生と比べて家族で情報源として「ラジオ等」が多か った（小学生と家族間差，男 $\mathrm{p}<0.05$, 女 $\mathrm{p}<0.001$ )。

「日常生活に打ける楽しみ」は，小学生では「スポー ツ」が男女各々 $50 \%$ と $30 \%$ と最も多く, 次に「祭などの 行事」「会話」の順であった。家族では「会話」が男女 各々 $39 \%$ と $46 \%$ と最も多く,「祭などの行事」,「ラジオ 等」の順であった（小学生と家族間差, 男 $\mathrm{p}<0.001$, 女 $\mathrm{p}<0.05)$ 。現在最も望むことは，小学生で「健康」 が男女各々 $40 \%$ と $54 \%$,「出世」 $48 \%$ と $37 \%$ に対して 「裕福」は $8 \%$ 以下と少なかった。家族では「健康」が $36 \%$ と $48 \%$,「出世」48\%と28\%で，「裕福」は15\%以下 と少なかった。

\section{5. 野菜の摂取頻度と睡眠や人間関係との関連性（表 5 ）}

小学生で「野菜の摂取が毎日」の場合に「熟睡」と答 えた割合が $51 \%$ ，「ぐっすり眠れない」が $9 \%$ でった のに対して, 野菜の摂取が「1 週間に 1 回以下」の場合 に「熟睡」と答えた割合が $17 \%$ と少なく「ぐっすり眠れ ない」が $25 \%$ と多かった $(\mathrm{p}<0.05)$ 。家族では「野菜 の摂取が毎日」の場合に「熟睡」と答えた割合が $63 \%$, 「ぐっすり眠れない」4\%であったのに対して, 野菜の 拱取が「 1 週間に1回以下」の場合に「熟睡」が45\%で, 「ぐっすり眠れない」が $22 \%$ と多かった $(\mathrm{p}<0.05) 。$

「人間関係への満足度」に対する野菜の摂取頻度の影 響をみると，小学生で「野菜を毎日摂取」と答えた場合 に「人間関係に満足している」と答えた割合が $73 \%$ と多 く，「満足していない」が18\%であった。「野菜の摂取が

表 5 野菜摂取頻度に対する睡眠と人間関係の関連性

$(\%)$

\begin{tabular}{|c|c|c|c|c|c|c|c|c|}
\hline \multirow{2}{*}{ 調 查 項 目 } & \multicolumn{4}{|c|}{ 小学生の野菜摂取頻度 } & \multicolumn{4}{|c|}{ 家族の野菜摂取頻度 } \\
\hline & 毎日 & $2 \sim 3$ 回/週 & 1 回以下/週 & $\chi^{2 \text { 検定 }}$ & 毎日 & $2 \sim 3$ 回/週 & 1 回以下/週 & $\chi^{2 \text { 検定 }}$ \\
\hline \multicolumn{9}{|l|}{ 睡眠 } \\
\hline 熟睡 & 50.5 & 33.3 & 16.7 & & 62.7 & 26.3 & 44.5 & \\
\hline 時々眠れない & 40.2 & 33.3 & 58.3 & $\mathrm{p}<0.05$ & 33.3 & 63.2 & 33.3 & $\mathrm{p}<0.05$ \\
\hline ぐっすり眠れない & 9.3 & 33.3 & 25.0 & & 4.0 & 10.5 & 22.2 & \\
\hline \multicolumn{9}{|l|}{ 人間関係に満足している } \\
\hline はい & 72.6 & 61.1 & 35.7 & & 93.4 & 79.0 & 55.6 & \\
\hline いいえ & 17.6 & 11.1 & 35.7 & $\mathrm{p}<0.05$ & 5.3 & 10.5 & 22.2 & $\mathrm{p}<0.01$ \\
\hline どちらともいえない & 9.8 & 27.8 & 28.6 & & 1.3 & 10.5 & 22.2 & \\
\hline
\end{tabular}


1 週間に 1 回以下」の場合に「人間関係に満足している」 が36\%と少なく「満足していない」が36\%と多かった $(\mathrm{p}<0.05)$ 。家族で「野菜を毎日摂取」と答えた場合に 「人間関係に満足している」が93\%と多く「満足してい ない」が $5 \%$ と少なく,「野菜の摂取が 1 週間に1回以下」 の場合に「満足している」が56\%と少なく,「満足して いない」が $22 \%$ と多かった（p<0.01）。

\section{6. 睡眠と体調や団欒との関連性（表 6 ）}

小学生で「熟睡」と答えた場合に「疲れている」は4 \%に対して「ぐっすり眠れない」場合に「疲れている」 が28\%と多かった（p<0.001）。家族では「熟睡」の場 合に「疲れている」が19\%に対して「時々眠れない」場 合に「疲れている」が34\%と多かった（p<0.05）。

「睡眠」と日常生活との関連性をみると, 小学生では 「熟睡」の場合に「楽しく過ごしている」が80\%であっ たのに対して「ぐっすり眠れない」では $65 \%$ と少ない傾 向がみられた。家族では「熟睡」の場合に「楽しく過ご している」が95\%であったのに対し，「時々眠れない」 と「ぐっすり眠れない」場合に「楽しく過ごしている」 が各々 $70 \%$ と $86 \%$ と少なかった $(\mathrm{p}<0.01)$ 。
「睡眠」と「団戀」に対する認識との関連をみると， 「熟睡」の場合に小学生で「家族と食事をしながら話を することが楽しみ」と答えた割合が $77 \%$ と多かったが， 「ぐっすり眠れない」場合に「楽しみにしている」が47 $\%$ と少なく，「いいえ」が41\%と多かった（p<0.001）。 家族では「熟睡」の場合に「楽しみ」が91\%に対し, 「ぐっすり眠れない」場合に「楽しみ」が71\%と少なく 「いいえ」が14\%と多かった（ $\mathrm{p}<0.01 ） 。$

\section{7 . 食習慣への認識と体調や日常生活との関連性（表 7 )}

小学生で「健康に適した食生活をしている」と答えた 場合に「疲れている」は $5 \%$ に対して，「どちらともい えない」と答えた場合に「疲れている」は25\%と多い傾 向がみられた。家族では「健康に適した食生活をしてい る」と答えた場合に「体調がよい」は25\%で，「疲れて いる」が23\%であった。「健康に適した食生活をしてい ない」と答えた場合に「体調がよい」は $9 \%$ 「疲れて いる」が41\%と多かった（p<0.05）。

食習慣への認識と日常生活との関連性をみると，小学 生では「健康に適した食生活をしている」と答えた場合

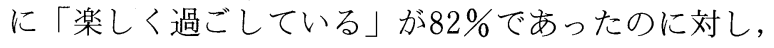

表 6 睡眠状況に対する体調, 日常生活と団欒の関連性

$(\%)$

\begin{tabular}{|c|c|c|c|c|c|c|c|c|}
\hline \multirow{2}{*}{ 調 査 項 目 } & \multicolumn{4}{|c|}{ 小学生の睡眠状況 } & \multicolumn{4}{|c|}{ 家族の睡眠状況 } \\
\hline & 熟睡 | & 時々眠れない & ぐっすり眠れない & $\chi^{2}$ 検定 & 熟睡 & 時々眠れない & ぐっすり眠れない & $\chi^{2}$ 検定 \\
\hline \multicolumn{9}{|l|}{ 体調 } \\
\hline よい & 29.1 & 22.6 & 33.3 & \multirow{3}{*}{$\mathrm{p}<0.001$} & 27.6 & 7.3 & 28.6 & \multirow{3}{*}{$\stackrel{\mathrm{ns}}{\left(\mathrm{p}<0.05^{*}\right)}$} \\
\hline 普通 & 67.3 & 77.4 & 38.9 & & 53.4 & 58.6 & 42.8 & \\
\hline 疲れている & 3.6 & 0.0 & 27.8 & & 19.0 & 34.1 & 28.6 & \\
\hline \multicolumn{9}{|l|}{ 楽しく過ごしている } \\
\hline はい & 79.6 & 78.2 & 64.7 & \multirow{3}{*}{ ns } & 94.7 & 70.0 & 85.7 & \multirow{3}{*}{$\mathrm{p}<0.01$} \\
\hline いいえ & 5.1 & 7.3 & 0.0 & & 5.3 & 15.0 & 14.3 & \\
\hline どちらともいえない & 15.3 & 14.5 & 35.3 & & 0.0 & 15.0 & 0.0 & \\
\hline \multicolumn{9}{|c|}{ 家族と食事をしながら話をすることが楽しみである } \\
\hline はい & 76.8 & 43.4 & 47.0 & \multirow{3}{*}{$\mathrm{p}<0.001$} & 91.4 & 92.5 & 71.4 & \multirow{3}{*}{$\mathrm{p}<0.01$} \\
\hline いいえ & 12.5 & 49.1 & 41.2 & & 8.6 & 7.5 & 14.3 & \\
\hline どちらともいえない & 10.7 & 7.5 & 11.8 & & 0.0 & 0.0 & 14.3 & \\
\hline
\end{tabular}

*家族の睡眠状況に対する「ぐっすり眠れない」は除外

表 7 健康に適した食生活への認識に対する体調と日常生活の関連性

\begin{tabular}{|c|c|c|c|c|c|c|c|c|}
\hline \multirow{2}{*}{ 調 査 項 目 } & \multicolumn{4}{|c|}{ 小学生の「健康に適した食生活をしている」 } & \multicolumn{4}{|c|}{ 家族の「健康に適した食生活をしている」 } \\
\hline & はい & いいえ & どちらともいえない & $\chi^{2}$ 検定 & はい & いいえ & どちらともいえない & $\chi^{2}$ 検定 \\
\hline \multicolumn{9}{|l|}{ 体調 } \\
\hline よい & 28.4 & 22.2 & 25.0 & \multirow{3}{*}{ ns } & 25.3 & 9.1 & 0.0 & \multirow{3}{*}{$\mathrm{p}<0.05$} \\
\hline 普通 & 66.7 & 72.2 & 50.0 & & 52.0 & 50.0 & 90.9 & \\
\hline 疲れている & 4.9 & 5.6 & 25.0 & & 22.7 & 40.9 & 9.1 & \\
\hline \multicolumn{9}{|l|}{ 楽しく過ごしている } \\
\hline はい & 81.9 & 61.1 & 37.5 & \multirow{3}{*}{$\mathrm{p}<0.05$} & 87.7 & 77.3 & 81.8 & \multirow{3}{*}{$\begin{array}{c}\mathrm{ns} \\
\left(\mathrm{p}<0.05^{*}\right)\end{array}$} \\
\hline いいえ & 4.5 & 5.6 & 25.0 & & 5.5 & 22.7 & 9.1 & \\
\hline どちらともいえない & 13.6 & 33.3 & 37.5 & & 6.8 & 0.0 & 9.1 & \\
\hline
\end{tabular}

*家族の「健康に適した食生活をしている」に対する「どちらともいえない」は除外 
「健康に適した食生活をしていない」場合に「楽しく過 ごしている」が $61 \%$ と少なかった（p<0.05）。家族で は「健康に適した食生活をしている」場合に「楽しく過 ごしていない」が $6 \%$ であったのに対し，「健康に適し た食生活をしていない」場合に「楽しく過ごしていない」 が23\%と多かった（p<0.05）。

\section{考察}

調査対象の家族の契煙と飲酒習慣は，日本の 20 歳以上 の哭煙（男女各々 $47 \%$ と $12 \%$ ）や飲酒習慣（男女各々 51 \%と $9 \%)^{8)}$ と比較して低かった。長期のケシ栽培によ りアヘン中毒が懸念されている山岳住民であるが6), 調 査地域では喫煙率が低く飲酒習慣も少なく健康的な暮ら しであることが推察された。

穀類の摂取頻度を比較すると，米の摂取頻度が $90 \%$ 以 上と多く，米を主に摂取し不足をとうもろこしで補足す る伝統的な食習慣が維持されていた。小学校の昼食も飯 が提供されており小麦製品の生活への普及は少なく，夕 イ山村部で朝食のパン食が $4 \%$ との報告3) と同傾向であ った。

芋類や豆類の摂取頻度に対して，対象者の $60 \%$ 以上が 「週に 1 回以下」で頻度が少なかった。野菜類の摂取頻 度は穀類に次いで多かったが，レタス，白菜等収入源の 販売用に大量栽培されている野菜に限定されており野菜 の種類は少なかった。住民の健康のために芋類や豆類の 栽培や摂食用の人参, トマトなど多くの種類の野菜を栽 培することを指導することが望まれる。また，果実類の 摂取頻度が低かったが，その要因として，調査地で栽培 されていないことと経済的理由によると推定される。

魚介類の摂取頻度が低い要因として，山間部のため魚 介類が得られず摂食習慣がなかったことと，平地から輸 送された冷凍魚の購入は可能であるが高価であることに よると推察される。魚介類に含まれるエイコサペンタエ ン酸などの脂肪酸が生活習慣病を予防することから魚介 類の摂取が大事である。山女などの川魚の放流や養殖な どの施策が魚介類の摂取を増加させ，住民の健康に役立 つと思われる。

肉類が貴重な動物性蛋白質源であり，飼育しているこ とから主に豚肉や鵎肉が㩒取されている。しかしながら 小学生の $50 \%$ 以が「週に 1 回以下」と攝取頻度が低く, 今後の成長のためにも摂取を促進させる方策の必要性が 示唆された。

鶏を飼育していることから卵類は動物性蛋白質源の中 で最も多い頻度で摂取されていたが，小学生で36\%以上 が「週に 1 回以下」であった。卵類が肉類や魚介類より も安価で入手容易であると考えられることから，動物性 蛋白質源の摂取促進のために䳕の飼育を推奨することが， 卵類の摂取を促進させることに有効と思われる。

乳類，乳製品の摂取頻度は低かったが，その要因とし て従来の焼畑移動生活で乳類の摂取習慣がなかったこと
によると思われる。ネパール山岳住民は放牧を生活の糧 としていることから乳類の摂取頻度は高かった9)。国策 により定住化が進められているが，山間部での放牧を生 活に取り入れることによって乳類の摂取を増加すること が可能と思われる。

油脂類は炒め物に使用されるが，動物脂が植物油より も摂取が多かった。その理由として, 植物油は購入可能 であるが豚を飼育していることからラードが入手容易で あることによると推定される。

啫好飲料を比較すると, 茶の摂取頻度が低かったが, 従来の焼畑移動生活では飲茶の習慣がなかったことが推 定される。定住化後, コーヒー, シュースなどの缶飲料 が入手可能となり, 特に家族男に都会型の飲料摂取習慣 が生じていることが認められた。

米を除くと全般的に食品摂取頻度が低く，このことは

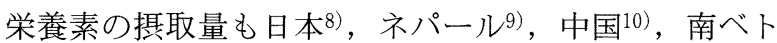
ナム ${ }^{11)}$ と比べて少ないことを示唆している。摄取頻度が 低い要因として自給自足の生活と貧しい経済状況の実情 を反映していると推察される。栄養成分が成長や健康維 持に非常に重要であり, 肉類, 牛乳などの低㨟取の場合 に精神的健康度も低い12)ことからも，心身の健康のため に摂取の増加が必要と思われる。教育が食生活を改善す る13) と考えられることからも栄養の重要性に対する教育 や実施のための施策の早急な確立が必要と思われる。

小学生で契食率が低かったが，その要因として経済的 理由による欠食が推察された。欠食によって栄養素の摂 取が低下し ${ }^{8)}$, 精神的症状に対する訴えの増加 ${ }^{14)}$ が認め られていることから, 今後の小学生の心身の健全な成長 のために，朝食の給食などの契食対策が望まれる。

瘦せ願望が少なかったが，タイの山村ではダイエット 志向は全くみられないとの宇都宮らの報告と合致し1), 都市部と異なり地方では食糧が充分でないことも要因で あると思われる。

食生活への認識をみると,「健康に適した食生活をし ている」と答えた割合は $64 \%$ 以上で，日本の成人男女 (各々 $66 \%$ と $83 \%)^{15)}$ と同程度であった。本調査対象者の 摂取栄養素量は日本と比べて少なく栄養不足が示唆され た。しかしながら「健康に適した食生活をしている」と の認識は高く矛盾が認められた。栄湌教育を行い, 認識 と合致するような健康に適した食生活が可能になる施策 が望まれる。

仕事，家事，運動などで 1 日に体を動かす時間は家族 では「7 時間以上」が男 $78 \%$ ，女56\%と多かった。特に 「体を動かす時間」は家族の男で最も多かったが，農業 に従事している時間が長いことによると推察される。小 学生と比べて家族の方が「疲れている」が多かったが， その要因として，農作業による疲れと同時に栄養不足に よる疲労回復の遅れが推測される。また, 小学生で「3 〜 4 時間」以上が男女ともに $54 \%$ 以上と多かった。「日 常生活上の仕事を家族全員で分担しなければならない」 
との認識が家族と同程度であったことから判断すると農 業を手伝っていることが推察される。

「日常生活に打ける楽しみ」は家族で「会話」が最も 多く,「会話」を最も楽しむネパールの山岳住民と同傾 向であった ${ }^{16)}$ 。家族では団緗を楽しみにし，家族の $84 \%$ 以上が人間関係に満足していることはストレスを感じな い精神上健康的に暮らしていることが窺えた。しかしな がら, 毎日の生活について「楽しく過ごしている」と答 えた割合や「人間関係に満足している」と答えた割合が 小学生で少なかった。このことは，成人とは異なる若年 者の悩みがあることが推察された。

家族で「伝統的な習慣は人々の絆や支えになっている」 と答えた割合が多く, 伝統的な習慣に対して価值を認め ていることが窥えた。また，「伝統的な習慣は人々の絆 や支えになっている」と答えた割合は, 日本人（男女各 々 $65 \%$ と $69 \%$ ) よりも多く, ネパールの山岳住民 (90\%) 之同程度で, 伝統的な習慣への価値観が高かった ${ }^{16)}$ 。小 学生で伝統的な習慣に対する価值観が低かったが，その 要因として，若年者では社会変化に対する柔軟性や都市 部での生活への憧れが強いことを反映していると思われ る。

睡眠に対して「熟睡」が小学生で少なく，「眠れない」 がタイ3)の都市部 $(20 \%)$ や山村部 (29\%) の小学生と 比べて多かった。本調査で, 野菜の摂取頻度が低いと熟 睡出来ず睡眠に影響を与えることが示唆された。健康管 理のために野菜の摄取頻度を推奨し，睡眠状況を改善す ることが望まれる。

野菜の摂取頻度と人間関係への満足度とに関連性がみ られ，野菜の摂取頻度が人間関係の満足度に影響を与え ることが示唆された。野菜類の摂取頻度が低い場合に精 神健康度が低いことが報告されている12)ことからも，適 切な睡眠や人間関係など心身の健康維持のために野菜摂 取の教育が必要と思われる。

これらの関連性は, 睡眠が適切な場合に体調がよく, 楽しく過ごし，家族との会話を楽しんでいることを示唆 している。心身の健康的な生活維持のために適切な睡眠 の重要性が示唆され，睡眠の休息効果の低さが昼間の心 理的問題と関連すると考えられている17)ことからも, 適 切な睡眠が得られない要因の更なる検討と改善が望まれ る。

「健康に適した食生活をしている」と認識している場 合に体調がよく，楽しく過ごしていることが窅えた。心 身の健康に満足した生活のために適切な食習慣が重要で あることが示唆され，充分な食品摂取が可能となるよう な施策の必要性が示唆された。

\section{要 約}

タイ北部山岳少数民族 110 人（男 65 人，女 45 人，15～ 59 歳）及び $4 \sim 6$ 年生の小学生 145 人（男子 72 人，女子 73 人）を対象に 2003 年 8 月に食生活と保健要因への認識に
ついてアンケート調査を行った。

食品の摂取頻度を比較すると，米の「毎日摂取」は男 女各々 $91 \%$ と $99 \%$, 家族 $97 \%$ と $95 \%$ で，野菜類は小学生 $72 \%$ と79\%，家族63\%と88\%であったが，その他の食品 の摂取頻度は低かった。欠食状況を比較すると，「欠食 しない」は男女各々小学生 $74 \%$ と $80 \%$ で，家族男女とも 91\%よりも契食率が低かった（小学生と家族間差, 男 $\mathrm{p}<0.05$ )。

家族団欒に対して「楽しみ」は，小学生男 $47 \%$ よりも 女 $69 \%$ と多く，家族は男女とも $91 \%$ で小学生よりも団欒 を楽しみにしていた（小学生性差 $\mathrm{p}<0.05$, 小学生と家 族間差，男 $\mathrm{p}<0.001$, 女 $\mathrm{p}<0.05)$ 。「睡眠」に対して 「熟睡」が小学生で男 $36 \%$ で女 $54 \%$ よりも少なく，家族 男女各々 $47 \%$ と $66 \%$ で，小学生及び家族ともに適切な睡 眠がとれていないことが窥えた（小学生性差 $\mathrm{p}<0.05 ） 。$

「野菜の摂取頻度」と「睡眠」との関連性をみると, 野菜を「毎日摂取」と答えた場合に「熟睡」と答えた割 合が小学生, 家族ともに多く,「ぐっすり眠れない」が 少なかった（小学生と家族, 各々 $\mathrm{p}<0.05$ )。「野菜の摂 取頻度」と「人間関係への満足度」との関連性をみると, 野菜を「毎日摂取」と答えた場合に「人間関係に満足し ている」と答えた割合が小学生, 家族ともに多かった (小学生 $\mathrm{p}<0.05$, 家族 $\mathrm{p}<0.01$ )。

これらの結果から, 食品の摂取頻度や喫食率が低く栄 養不足が示唆され，特に野菜の摂取不足が「睡眠」や 「人間関係への満足度」に影響を与えることが認められ た。

\section{謝 辞}

本調査に御協力下さいました対象者の皆様に心よりお 礼申し上げます。また, 調査の実施にあたり多大なご助 力を賜わりました諸先生方ならびに村長を始め村民の皆 様に深謝いたします。

\section{参考文献}

1）宇都宮由佳, 益本仁雄 : 家政誌, 51, 913 (2000)

2）宇都宮由佳, 益本仁雄, 大澤清二：家政誌，53，561 (2002)

3）宇都宮由佳, 益本仁雄, 大澤清二：家政誌，54，365 (2003)

4）小野澤正喜編：アジア読本 タイ, 河出書房新社, 東京, p.202 (1994)

5）ジョージナ・アシュワース編：世界の少数民族を知る事 典, 明石書店, 東京, p.70 (1990)

6）ガリマール社・同朋舎出版編: タイ, 同朋舎出版, 京都, p.294 (1994)

7）山田均: 世界の食文化 5 タイ, 農山漁村文化協会, 東京 $(2003)$

8）健康·栄養情報研究会編 : 国民栄養の現状（平成12年厚 生労働省国民栄養調查結果), 第一出版, 東京 (2003)

9) Yoshimi Ohno, Kazuko Hirai, Noriko Sato, Masashi Ito, Teruko Yamamoto, Toshihide Tamura, Mathura P. 
Shrestha: Asia Pacific J. Clin. Nutr., 6, 251 (1997)

10）鄭 玉栄, 酒井映子, 末田香里: 栄養学雑誌, 62, 95 (2004)

11) Ta thi Tuyet Mai, Nguyen thi Kim Hung, Masanobu Kawakami, Van Chuyen Nguyen: J. Nutr. Sci. Vitaminol., 49, 13 (2003)

12）富永美穂子, 清水益治, 森 敏明, 児玉憲一, 佐藤一精 : 家政誌，52，499（2001）

13）古崎和代, 東川赾美, 菊地和美, 山本愛子, 山口敦子,
水野浄子, 平井和子：日本食生活学会誌, 14:274（2004）

14）原田まつ子：栄養学雑誌，46，175（1988）

15）武副礼子, 平井和子, 西村弘子, 青木洋子, 樋口 寿 : 日本食生活学会誌，9，48（1998）

16）大野佳美, 平井和子, 浅野真智子, 樋口 寿, 武副礼子 : 家政誌，52，391（2001）

17) Absolon CM, Cottrell D, Eldridge SM, Glover MT : Br. J. Dermatol., 137, 241 (1997) 